\title{
ISLAM ABANGAN DAN NASIONALISME KOMUNITAS SAMIN DI BLORA
}

\author{
Mukodi \\ Sekolah Tinggi Keguruan dan Ilmu Pendidikan (STKIP) PGRI Pacitan \\ e-mail:mukodi@yahoo.com \\ Afid Burhanuddin \\ Sekolah Tinggi Keguruan dan Ilmu Pendidikan (STKIP) PGRI Pacitan \\ e-mail: afidburhanuddin@gmail.com
}

\begin{abstract}
This study aimed at exploring the starting point of Islam Abangan and nationalism among Samin community in Blora regency. This research also aimed at exposing the resistance of Samin community Blora in recent time. For this research, qualitative approach and e phenomenological method were both used to get the accurate results. Relation between Islam Abangan and nationalism among Samin community in Blora were coherently intertwined and in harmony. The harmony were manifested through the daily practices of Samin community containing the teachings of Ki Samin Surosentiko. The c onsistency of the community in carrying out the teachings of Ki Samin Surosentiko caused them still exist to survive amid the onslaught of modernism currents. Thus, local culture, and Javanese Islam were the means to strengthen the attachment of humanity, to strengthen the humanity affinity as well as the seeds of nationalism spirit, in the regional locality, including in Blora.
\end{abstract}

Penelitian ini bertujuan untuk mengeksplorasi titik pangkal Islam Abangan, dan nasionalisme di komunitas Samin Kabupaten Blora. Selain itu, riset ini juga bertujuan untuk mengekspos daya tahan eksistensi komunitas Samin Blora yang masih hidup hingga kini. Agar menemukan hasil yang akurat riset ini menggunakan pendekatan kualitatif dengan metode fenomenologi. Relasi antara Islam Abangan, dan nasionalisme di kalangan komunitas Samin Brola terjalin padu, dan harmoni. Keharmonian keduanya terejawantahkan melalui praktik-praktik keseharian mereka yang merupakan nilai ajaran Ki Samin Surosentiko. Konsistensi komunitas Samin dalam menjalankan ajaran Ki Samin mengakibatkan mereka tetap eksis bertahan di tengah gempuran arus modernisme. Dengan demikian, kebudayaan lokal, dan Islam (Jawa) Abangan menjadi sarana untuk memperkokoh kelekatan kemanusiaan, sekaligus penyemai jiwa nasionalisme di bilik-bilik lokalitas kedaerahan, tak terkecuali di Blora.

Keywords: Islam Abangan; nationalism; Samin community; Blora 


\section{A. Pendahuluan}

Belakangan ini, Islam, dan nasionalisme acapkali dipersandingkan. Kedua term ini menjadi begitu diskursif tatkala mencermati fenomena kekerasan atas nama Islam di satu pihak, dan catatan historis di lain pihak. Lebih dari itu, Islam, dan nasionalisme seolah menemukan momentumnya manakala nilai-nilai keislaman, dan nasionalisme masyarakat diakar rumput (grassroot) mulai memudar. Indikasinya mudah diamati. Pelbagai kasus korupsi, ${ }^{1}$ narkoba, ${ }^{2}$ teorisme, ${ }^{3}$ dan radikalisme ${ }^{4}$ di Indonesia pelakunya mayoritas beragama Islam.

\footnotetext{
${ }^{1}$ Data yang dirilis lembaga Transparency International (TI) menyebutkan Indonesia menempati peringkat ke 88 dengan skor CPI 36 dari 168 negara yang diamati. Skor tersebut meningkat dua poin dari tahun 2014 yang berada di peringkat ke-107. Namun demikian, skor rata-rata tahun ini adalah 43. Artinya skor Indonesia masih di bawah rata-rata skor persepsi dunia. Di Asia Tenggara, Indonesia ada di bawah Singapura, Malaysia, dan Thailand. Lihat laman https://m.tempo.co/read/news/2016/01/27/ 063739957/ini-daftar-peringkat-korupsi-dunia-indonesia-urutan-berapa.

${ }^{2}$ Badan Narkotika Nasional (BNN) menyatakan transaksi narkoba yang ada di Indonesia menduduki peringkat tertinggi dibandingkan dengan negara-negara yang tergabung dalam organisasi ASEAN lainnya. Berdasarkan pertemuan BNN dengan badan atau menteri yang mengurusi narkotika se Asia Tenggara ternyata dari 100 persen transaksi narkotika di wilayah ASEAN, 40 persennya berada di Indonesia. Lihat laman http://www.antaranews.com/berita/474528/bnn-transaksi-narkoba-indonesiatertinggi-se-ASEAN.

${ }^{3}$ Berdasarkan catatan historis, selama dekade 2002 hingga 2016 setidaknya ada tujuh kasus terorisme terparah yang terjadi di Indonesia. Diawali peristiwa Bom Bali 1 yang terjadi pada tahun 2002. Bom ini merupakan rangkaian tiga peristiwa pengeboman terus-menerus yang terjadi pada malam hari tanggal 12 Oktober 2002. Dua ledakan pertama terjadi di Paddy's Pub, dan Sari Club (SC) di Jl. Legian, Kuta, Bali, sedangkan ledakan terakhir terjadi di dekat Kantor Konsulat Kedubes Amerika Serikat. Tercatat 202 korban jiwa meninggal, dan sedikitnya 209 orangluka-luka. Kemudian, pada 2003 bom kembali meledak di Hotel JW Mariott di kawasan Mega Kuningan, Jakarta. Ledakan itu berasal dari bom bunuh diri dengan menggunakan mobil Toyota Kijang, dikendarai oleh Asmar Latin Sani. Sebanyak 12 orang tewas, dan 150 orang cedera dalam kejadian ini. Pada 2004, ledakan besar terjadi tepat di depan kantor Kedutaan Besar Australia, kawasan Kuningan, Jakarta. Aksi teror ini merupakan rentetan serangan terorisme yang ditujukan terhadap Australia. Ada 11 orang tewas dalam aksi terror ini. Dilanjutkan 2005, bom bali 2 terjadi di Pulau Dewata Bali. Ledakan bom berada di R.AJA's Bar dan Restaurant, Kuta Square, daerah Pantai Kuta dan di Nyoman Cafe Jimbaran. Terjadi tiga pengeboman berurutan, satu di Kuta, dan dua di Jimbaran.Meski lebih kecil dari bom Bali pertama, peristiwa ini menewaskan 22 orang dan 102 orang mengalami luka-luka. Pada 2009, bom Hotel JW Mariott dan RitzCarlton. Peristiwa bom bunuh diri terjadi di hotel JW Mariott dan Ritz-Carlton. Peristiwa ini menewaskan 9 orang korban, dan melukai lebih dari 50 orang lainnya. Peristiwa ini terjadi sembilan hari sesetelah Pemilu Presiden dan Wakil Presiden Indonesia. Kemudian, bom Mapolresta Cirebon pada 2011 saat akan melakukan Salat Jumat. Berbeda dari aksi lainnya, bom bunuh diri ini ditujukan untuk menyerang Polisi. Tercatat ada 25 orang mengalami luka-luka dan menewaskan 1 orang pelaku. Kemudian, Bom Plaza Sarinah pada 2016. Bom Sarinah merupakan serentetan peristiwa bom sebanyak enam ledakan, dan juga teror penembakan di daerah sekitar Plaza Sarinah, Jl. MH. Thamrin, Jakarta.Ledakan terjadi di dua tempat, ledakan pertama terjadi tempat parkir Menara Cakrawala, gedung sebelah utara Sarinah, dan sebuah Pos Polisi di depan Plaza Sarinah tersebut. Sedikitnya delapan orang, empat dari pelaku penyerangan teror dan empat warga sipil dilaporkan tewas dan 24 lainnya luka-luka akibat serangan ini. Tujuh orang terhitung terlibat sebagai pelaku penyerangan Bom
} 
Di sisi yang sama, pendangkalan nasionalisme terjadi di mana-mana. Kasus pelecehan Lambang Negara yang melibatkan artis papan beberapa waktu lalu adalah bukti nyata. ${ }^{5}$

Poin terpenting yang harus dipahami, bahwa Islam dan nasionalisme sesungguhnya merupakan satu irisan yang saling berhubungan. Satu dan lainnya tidak dapat dipisahkan. Apalagi praktik keduanya di Indonesia dari waktu ke waktu saling melekat. Islam Abangan, dan nasionalisme komunitas Samin di Blora misalnya menjadi penanda dari daya lekat antar keduanya. Walau tidak sedikit orang masih meragukan hal itu.

Tak ayal, ajaran Kiai Samin Surosentiko menjadi fokus pengkajian para peneliti, baik dari dalam negeri, maupun manca negara. Pada umumnya mereka menggambarkan bahwa ajaran Kiai Samin merupakan sebuah ajaran yang unik yang memadukan pandangan-pandangan Kejawen yang merupakan local wisdom (kearifan lokal) dengan unsur-unsur tertentu dalam Islam, di samping juga ada anasir-anasir yang bersumber dari Hinduisme dan Budhisme. Ajaran Samin dipandang merupakan salah satu jenis ajaran Kejawen yang dipraktekkan dalam kehidupan sehari-hari dan mampu membentuk suatu komunitas yang eksklusif, yaitu sebagai orang Samin atau sering juga disebut sebagai Wong Sikep. ${ }^{6}$ Hanya saja, sedikit sekali para peneliti yang menjadikan Islam Abangan dan nasionalisme komunitas Samin Blora sebagai objek materialnya. Padahal, Islam Abangan, nasionalisme, dan komunitas Samin Blora merupakan wujud kesatuan ide.

Sarinah, dan organisasi Negara Islam Irak dan Syiria (ISIS) mengklaim bertanggung jawab sebagai pelaku penyerangan Teror di Kawasan Sarinah ini. Baca, http:// www.awas-aja.com/2016/02/7kasus-terorisme-heboh-terbesar-indonesia.html

4Berdasarkan survei Lembaga Kajian Islam dan Perdamaian (LaKIP) pada Oktober 2010 hingga Januari 2011, mengungkapkan hampir 50\% pelajar setuju tindakan radikal. Data itu menyebutkan $25 \%$ siswa dan $21 \%$ guru menyatakan Pancasila tidak relevan lagi. Sementara 84,8\% siswa dan 76,2\% guru setuju dengan penerapan Syari'at Islam di Indonesia. Jumlah yang menyatakan setuju dengan kekerasan untuk solidaritas agama mencapai 52,3\% siswa dan 14,2\% membenarkan serangan bom. Lebih dari itu, dalam survei The Pew Research Center pada 2015 lalu, mengungkapkan di Indonesia, sekitar $4 \%$ atau sekitar 10 juta orang warga Indonesia mendukung ISIS - sebagian besar dari mereka merupakan anak-anak muda. Lihat lebih lanjut, http://www.bbc.com/indonesia/berita_indonesia/ 2016/02/160218_indonesia_radikalisme_anak_muda.

5Baca http://www.cnnindonesia.com/nasional/20160318100313-12-118220/diduga-menghinalambang-negara-dahsyat-terancam-dihentikan/. Di sisi yang sama, para pemuda-pemudi Indonesia saat ini juga seolah tidakpeduliterkait hal ihwal mengenai nasionalisme. h. 34 .

${ }^{6}$ Singgih Tri Sulistiyono, "Saministo Phobia", Jurnal Sejarah Citra Lekha, Vol. XV, No. 2, Agustus 2011, 
Dalam konteks itu, penelitian ini akan difokuskan pada titik temu antara Islam Abangan, dan nasionalisme di komunitas Samin di Blora. Tujuan kajian ini setidaknya ada dua, yakni: 1) menemukan dan menganalisis titik pangkal Islam Abangan dan nasionalisme di komunitas Samin Kabupaten Blora; 2) menganalisis daya tahan eksistensi komunitas Samin Blora yang hidup hingga kini. Ada dua kontribusi ilmiah pada penelitian ini, yaitu kontribusi teoritik dan kontribusi praktis. Secara teoritik, hasil riset ini dapat memperkaya hazanah pengetahuan tentang titik temu Islam Abangan, dan nasionalisme di komunitas Samin Blora. Secara praktis, penelitian ini diharapkan dapat memberikan kontribusi secara nyata bagaimana komunitas Samin Blora dapat memadu antara Islam Abangan, dan semangat nasionalisme.

Metodologi penelitian yang digunakan dalam penelitian ini adalah pendekatan kualitatif, dengan menggunakan metode fenomenologi. Metode fenomenogis (phenomenological studies) mencoba mencari arti dari pengalaman dalam kehidupan. Peneliti menghimpun data berkenaan dengan konsep, pendapat, pendirian, sikap, penilaian, dan pemberian makna terhadap situasi atau pengalaman-pengalaman dalam kehidupan.

\section{B. Islam dan Nasionalisme: Sebuah Tinjauan Pustaka}

Belakangan ini, penelitian yang mengkaji persoalan tentang Islam, dan nasionalisme sangat kenyal, dan kaya. Para pembaca seolah dimanjakan dengan pelbagai perspektif, dan pendekatan darinya. Namun demikian, tetap saja ada ruang kosong, dan dialektika didalamnya. Kontruksi teoritik riset ini bertumpu pada tiga ranah, yakni: Islam, nasionalisme, dan Saminisme Blora.

\section{Islam Abangan}

Hingga kini karya Clifford Geertz yang berjudul The Religion of Java, atau dalam versi Indonesia dengan judul Abangan, Santri, Priyayi dalam Masyarakat Jawa menjadi buku induk dalam kajian Islam Jawa. Buku Geertz ini sesungguhnya merupakan ekspos dari hasil risetnya yang dilakukan di Mojokerto pada bulan Mei 1953 hingga September 1954. Menurut Geertz masyarakat Jawa diklasifikasikan menjadi tiga varian, yakni abangan, santri, dan priyayi. Namun demikian, beragam sanggahan, dan penolakan atas ketidaktepatan pengklasifi- 
kasian ala Clifford Geertz tersebut terus berkembang. Hanya saja, laiknya sebuah teori pasti ada pro-kontra, dan masing-masing ada pengikutnya.

Di antara kajian yang menolak konsepsi Geertz adalah Mark R. Woodward. Penelitiannya merupakan sanggahan terhadap konsepsi Geertz bahwa Islam Jawa adalah Islam sinkretik yang merupakan campuran antara Islam, Hindu Budha dan Animisme. Melalui kajian secara mendalam terhadap agama-agama Hindu di India, yang dimaksudkan sebagai kacamata untuk melihat Islam di Jawa yang dikenal sebagai paduan antara Hindu, Islam dan keyakinan lokal, ternyata tidak ditemui unsur tersebut di dalam tradisi keagamaan Islam di Jawa, padahal yang dikaji adalah Islam yang dianggap paling lokal, yaitu Islam di pusat kerajaan, Yogyakarta. Menurutnya Islam dan Jawa adalah compatible dan merupakan varian wajar dalam Islam sebagaimana Islam India, Islam Persia, Islam Melayu dan sebagainya. ${ }^{7}$

Lebih dari itu, Andrew Beatty menyatakan bahwa Geertz dianggap terlalu berlebihan dalam melukiskan jarak antara ketiga varian santri, priyayi dan abangan tersebut. Beatty memandangnya sebagai entitas yang saling menyapa. Jika selametan atau kenduren dalam pandangan Geertz sebagai bentuk ritual kalangan abangan, Beatty melihatnya justru sebagai ritual bersama, di mana keragaman berkumpul membentuk harmoni dengan membiarkan masingmasing kelompok memaknai menurut perspektifnya sendiri.8 Poin terpenting yang harus diperhatikan dari buku The Religion of Java adalah klasifikasi varian Jawa ala Geertz tetap dijadikan referensi utama oleh para peneliti dalam memotret Islam Jawa. Dengan kata lain, buku Geertz ini menjadi bangunan dasar dalam memahami Islam Jawa di abad ke-20.

\section{Nasionalisme}

Nasionalisme secara etimologi berasal dari kata "nasional" dan "isme" yaitu paham kebangsaan yang mengandung makna kesadaran dan semangat cinta tanah air, memiliki kebanggaan sebagai bangsa, atau memelihara kehormatan bangsa, memiliki rasa solidaritas terhadap musibah dan kekurangberuntungan

\footnotetext{
${ }^{7}$ Mark R. Woodward dalam Vita Fitria, "Interpretasi Budaya Clifford Geertz: Agama sebagai Sistem Budaya”, Jurnal Sosiologi Reflektif, Vol. 7. No. 1, Oktober, 2012, h. 63.

${ }^{8}$ Ibid.
} 
saudara setanah air, sebangsa dan senegara serta menjunjung tinggi nilai persatuan dan kesatuan. ${ }^{9}$ Alih kata, nasionalisme dapat diartikan sebagai paham tentang kebangsaan dan sikap cinta tanah air yang tinggi yang harus dimiliki oleh warga negara, merasa memiliki sejarah dan cita-cita yang sama dalam tujuan berbangsa dan bernegara. Nasionalisme adalah jiwa dan semangat yang membentuk ikatan bersama, baik dalam hal kebersamaan maupun dalam hal pengorbanan. Perjuangan nasionalisme adalah untuk melepaskan diri dari aneka bentuk ikatan dan dominasi kesuasaan sosial dan politik lama, seperti suku bangsa, raja feodal, dinasti, untuk kemudian menyerahkan kekuasaan tertingginya pada negara kebangsaan. ${ }^{10}$

Akar-akar nasionalisme dapat pula diketemukan dalam ayat-ayat al-Qur'an ${ }^{11}$ dan dalam kehidupan Nabi Mahammad. ${ }^{12}$ Hal inilah yang membuat kalangan Islam nasionalis berani memperjuangkan berdirinya Negara Kesatuan Republik Indonesia tanpa mendasarkan diri formalisasi syariat Islam. Kelompok ini menyatakan bahwa kehidupan spiritual diatur oleh agama sedangkan kehidupan duniawi diatur oleh logika duniawi. Pemikiran ini seakan-akan mengandung unsur sekularistik, yaitu adanya pemisahan agama dengan dunia, meskipun sejatinya hanya pemisahan wilayah. Pemikiran seperti dapat mengalirkan pemikiran "Islam politik" ke Islam kultural.13

\footnotetext{
${ }^{9}$ Baca: Mifdal Zusron Alfaqi, "Memahami Indonesia Melalui Prespektif Nasionalisme, Politik Identitas, Serta Solidaritas" Jurnal Pendidikan Pancasila dan Kewarganegaraan, No. 2 Agustus 2015, h. 24.

10I Nengah Suastika, "Nasionalisme dalam Perspektif Postmodernisme, Poststrukturalisme, dan Postkolonialisme," Jurnal Media Komunikasi, Vol. 11 , No 1, April 2012, Fakultas Ilmu Sosial, Universitas Pendidikan Ganesha, Singaraja, h. 42.

11"Dan (ingatlah), ketika Ibrahim berdoa: "Ya Tuhanku, jadikanlah negeri ini, negeri yang aman sentosa.." (QS. al Baqarah [2]: 126]. "Dan (ingatlah), ketika Ibrahim berkata: "Ya Tuhanku, jadikanlah negeri ini (Mekah), negeri yang aman, dan jauhkanlah aku beserta anak cucuku daripada menyembah berhala-berhala." (QS. Ibrahim [14]: 35). "Aku benar-benar bersumpah dengan kota ini (Mekah)" (QS. al-Balad [90]: 1). "... (Negerimu) adalah negeri yang baik dan (Tuhanmu) adalah Tuhan Yang Maha Pengampun." (QS. Saba' [34]: 15). "Dan Kami jadikan antara mereka dan antara negeri-negeri yang Kami limpahkan berkat kepadanya, beberapa negeri yang berdekatan dan Kami tetapkan antara negeri-negeri itu (jarak-jarak) perjalanan. Berjalanlah kamu di kota-kota itu pada malam hari dan siang hari dengan dengan aman" (QS. Saba' [34]:18).

12"Diriwayatkan dari Ibnu Abbas bahwa saat Nabi diusir dari Makkah beliau berkata: Sungguh aku diusir darimu (Makkah). Sungguh aku tahu bahwa engkau adalah Negara yang paling dicintai dan dimuliakan oleh Allah. Andai pendudukmu (Kafir Quraisy) tidak mengusirku dari mu, maka aku takkan meninggalkanmu (Makkah)" (al-Hafiz al-Haythami, Musnad al-Hārith, 1/460).

${ }^{13}$ Abdul Choliq Murod, "Nasionalisme dalam Perspektif Islam", Jurnal Sejarah Citra Lekha, Vol. XV, No. 2, Agustus, 2011,h.45-58.
} 
Dalam pandangan A.F.K. Organski, nasionalisme berkembang melalui empat fase. Tahap I dari perkembangan politik kesatuan nasional primitif. Fase II dari tahap perkembangan politik industrialisasi. Fase III dari tahap perkembangan politik kesejahteraan nasional. Fase IV dari tahap perkembangan politik kemakmuran. Sedangkan cita-cita nasionalisme menurut Hertz ada empat macam: a) Perjuangan untuk mewujudkan persatuan nasional yang meliputi persatuan dalam politik, ekonomi, keagamaan, kebudayaan, dan persekutuan serta solidaritas; b) Perjuangan untuk mewujudkan kebebasan nasional yang meliputi kebebasan dari penguasa asing atau campur tangan dari dunia luar dan kebebasan dari kekuatan-kekuatan intern yang bersifat anti nasional atau yang hendak mengesampingkan bangsa dan negara; c) Perjuangan untuk mewujudkan kesendirian (separateness), pembedaan (distinctiveness), individualitas dan keaslian (originality); d) Perjuangan untuk mewujudkan pembedaan diantara bangsa-bangsa yang memperoleh kehormatan, kewibawaan, gengsi dan pengaruh. ${ }^{14}$ Dengan demikian, nasionalisme sejatinya adalah sebuah perjuangan untuk membebaskan segala penindasan, baik dari dalam, maupun dari luar menuju tujuan berbangsa dan bernegara.

\section{Saminisme Blora}

Saminisme Blora merupakan sebutan bagi pengikut (komunitas) Samin Surosentiko yang hidup, dan beranak-pinak di Blora. Komunitas Samin memiliki ciri-ciri khusus yang menjadi identitas mereka dalam penampilan seharihari yang berbeda dengan masyarakat di sekitarnya. Identitas tersebut menunjukkan karakter, dan perlengkapan mereka sesuai dengan ajaran Saminisme yang mereka pertahankan dari waktu ke waktu terutama generasi tua. ${ }^{15}$ Samin merupakan nama seorang priyayi-petani di Blora yang bernama Samin Surosentiko atau disebut dengan Raden Kohar (1859), ${ }^{16}$ yang menyebarkan pandangan hidup dengan menolak represi Kolonial pada pergantian abad ke-19-20. Samin kemudian menjadi ideologi dan identitas gerakan bagi

\footnotetext{
${ }^{14} \mathrm{Ibid}$, h. 48.

${ }^{15}$ Indah Puji Lestari, "Interaksi Sosial Komunitas Samin dengan Masyarakat Sekitar", Jurnal Komunitas, Vol. 5, No. 1, Maret, 2013, h. 75.

${ }^{16}$ Arif Rohman, "Rumour and Realities of Marriage Parctices in Contemporary Samin Society," Jurnal Humaniora, Vol. 22, No. 2, Juni, 2010, h.115.
} 
petani pada zaman Kolonial, yang sampai saat ini masih ditemukan jejaknya. Menurut Koerver dalam Munawir Aziz ${ }^{17}$ pengikut Samin juga dianggap sebagai sedulur sikep, yang banyak tersebar di Blora, Pati, Kudus, Bojonegoro, Madiun dan beberapa kawasan sekitarnya. Pada masa Kolonial, Samin Surosentiko (Raden Kohar) sebagai tokoh gerakan Samin menghimpun sebagian petani di desa-desa di Jawa Tengah dan Jawa Timur untuk melawan penjajah, dengan menolak membayar pajak, dan hal semacamnya yang berusaha menolak represi penguasa atas rakyat.18

Lazimnya komunitas Samin lainnya, mereka pun memiliki watak yang nerimo (menerima), dan apa adanya. Meminjam istilahnya Munawir Aziz masyarakat Samin seringkali menggunakan 'ilmu bodon', penuh keluguan, dan kejujuran dalam melakukan pelbagai aktivitas. ${ }^{19}$ Sebut saja, tatkala orang lain menanyakan sesuatu, dan sesuatu yang ditanyakan itu tidak menyenangkan hatinya, seperti misalnya, ketika bertemu dengan orang Samin dan bertanya, Dulur soko endi? (Kamu dari mana). Jawabnya, singkat, dan datar, "Ko mburi" (saya dari belakang). Padahal, kata belakang pengertian umumnya adalah sebuah tempat untuk membuang air besar atau air kecil, namun istilah,"buri" bagi orang Samin maksudnya bukan demikian, melainkan menunjukkan arah dari mana ia berangkat yang dirahasiakan. ${ }^{20}$ Padahal, kalamat-kalimat tersebut di zamannya digunakan untuk taktik, dan strategi politik warga Samin untuk melawan bangsa Belanda. Namun dalam perkembangannya, kalimat-kalimat tersebut digunakan warga Samin sebagai bahasa keseharian mereka.

Ajaran Ki Samin Surosentiko yang hingga kini dipraktikkan oleh komunitas Samin Blora, diantaranya: a) pantangan untuk tidak boleh drengki (membuat fitnah); b) tidak boleh srei (serakah); tidak boleh panasten (mudah tersinggung atau membenci sesama); c) tidak boleh da'wen (mendakwa tanpa bukti); d) tidak

\footnotetext{
17Munawir Aziz, "Identitas Kaum Samin Pasca Kolonia Pergulatan Negara, Agama, dan Adat dalam Pro-Kontra Pembangunan Pabrik Semen Di Sukolilo, Pati, Jawa Tengah" Jurnal Kawistara, Vol. 2, No. 3, Desember 2012, h. 252-263.

18Puji Lestari, “Analisis Perubahan Sosial pada Masyarakat Samin: Studi Kasus di Desa Mendenrejo, Kecamatan Kradenan, Blora” Jurnal Dimensia, Vol. 2, No. 2, September 2008, h. 23.

${ }^{19}$ Munawir Aziz, "Identitas Kaum Samin..., h. 1.

${ }^{20}$ Sadiran, "Pendidikan Moral Pada Masyarakat Samin Blora", Jurnal Al-Mabsut, Vol 6, No 1, April 2013, h. 8.
} 
boleh kemeren (iri hati/syirik, keinginan untuk memiliki barang yang dimiliki orang lain); e) tidak boleh nyiyo marang sapodo (berbuat nista terhadap sesama penghuni alam); f) tidak boleh bedok (menuduh); g) tidak boleh colong (mencuri); h) tidak boleh pethil (mengambil barang yang masih menyatu dengan alam atau masih melekat dengan sumber kehidupanya); i) tidak boleh jumput (mengambil yang telah menjadi komuditas di pasar); j) tidak boleh nemu (menemukan barang menjadi pantangan). ${ }^{21}$

Lebih dari itu, setidaknya ada lima pantangan dasar ajaran Samin, meliputi: a) tidak boleh mendidik dengan pendidikan formal; b) tidak boleh bercelana panjang; c) tidak boleh berpeci; d) tidak diperbolehkan berdagang; e) dan tidak diperbolehkan beristri lebih dari satu. ${ }^{22}$ Dengan demikian, ajaran Samin Surosentiko momot (memuat) nilai-nilai kearifan lokal dan budaya bangsa.

\section{Melacak Islam Abangan di Blora}

Blora adalah sebuah kota kecil yang terletak di ujung timur Propinsi Jawa Tengah. Sebelah barat berbatasan dengan Kabupaten Grobogan, sebelah utara berbatasan dengan Kabupaten Rembang, di sebelah timur berbatasan dengan Kabupaten Bojonegoro (Jawa Timur), dan sebelah selatan berbatasan dengan Kabupaten Ngawi (Jawa Timur). ${ }^{23}$ Jumlah penduduk Blora pada tahun 2015 sebesar 852.008 jiwa, dengan seks rasio 96,93 persen, artinya penduduk perempuan lebih banyak dibanding penduduk laki-laki. Tingkat kepadatan penduduk di Kabupaten Blora tahun 2015 rata-rata adalah 468 jiwa per km.2 Kepadatan tertinggi tercatat di Kecamatan Cepu sebesar 1.497 jiwa per km. ${ }^{2}$

Sepanjang sejarahnya, Blora merupakan wilayah yang terdiri dari hamparan hutan jati berkualitas tinggi dan tanah yang kering, tandus serta berkapur. Namun, siapa yang menyangka, dengan kondisi alam seperti demikian, Blora menyimpan keragaman tradisi yang kuat dan harus tetap dilestarikan. Salah

\footnotetext{
${ }^{21}$ Emillia Vinna Octaviani, “ Pola Komunikasi Suku Samin di Kabupaten Blora Terkait Ajaran yang Dianutnya”, Jurnal The Messenger, Vol. VII, No. 2, Juli 2015, h. 28.

${ }^{22}$ Ibid.

${ }^{23}$ Lebih dari itu, luas wilayah Kabupaten Blora adalah sebesar 1.820,59 $\mathrm{Km}^{2}$, dengan ketinggian terendah 25 meter dpl, dan tertinggi 500 meter dpl. Ia diapit oleh jajaran pegunungan Kendeng Utara, dan pegunungan Kendeng Selatan. Baca, Seksi IPDS, Blora dalam Angka: Blora in Figures 2016, (Blora: Badan Pusat Statistik Kabupaten Blora, 2016), h. 5.
} 
satunya, di desa Klopoduwur, Kecamatan Banjarejo, Kabupaten Blora sekitar 7 kilometer ke selatan dari pusat kota Blora.

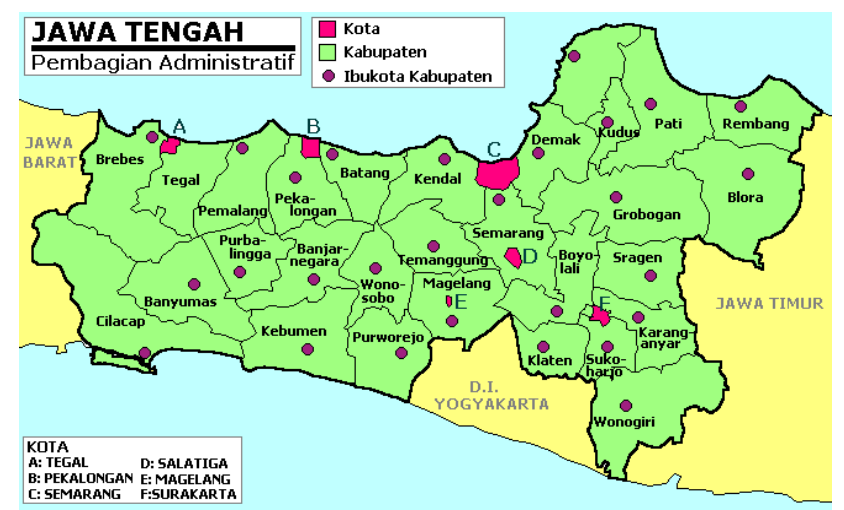

Gambar 1.

Kabupaten Blora dalam Peta Jawa Tengah

Berbasis Pembagian Administratif

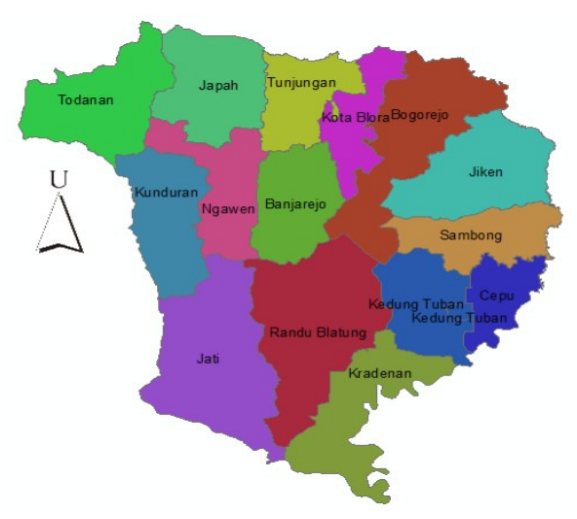

Gambar 2.

Peta Kabupaten Blora Berbasis Kecamatan

Mayoritas mata pencaharian penduduk Kabupaten Blora adalah pertanian utamanya tanaman pangan. Tahun 2015 gabah kering giling yang dapat dihasil- 
kan sebanyak 403.067 ton. Apabila dibandingkan dengan tahun 2014, terdapat kenaikan produksi sebesar 3,69\%. Hal ini disebabkan adanya kenaikan luas panen sebesar 7,93\% yakni dari 74.936 hektar menjadi 80.877 hektar. Angka luas panen ini merupakan angka luas panen bersih sesudah dikurangi galengan (pematang) dan lainnya. ${ }^{24}$ Di desa tersebut terdapat sekelompok masyarakat yang sering kali banyak pihak menganggapnya unik. Masyarakat tersebut adalah masyarakat Samin. ${ }^{25}$

Anggota dari komunitas masyarakat Samin dikenal dengan julukan Wong Samin, Wong Sikep, atau Wong Ādam. Dikatakan sebagai Wong Samin karena masyarakat ini merupakan pengikut dari Samin Surosentiko. Ia dilahirkan di desa Ploso Kedhiren, sebelah utara Randhublatung, Blora pada tahun 1859. Saat itu Bupati Blora dijabat oleh Adipati Cakranegara II yang memerintah dari tahun 1857 sampai tahun 1886. Belum ada sumber pasti yang menyebutkan tanggal dan bulan kapan ia dilahirkan. Hal ini dimungkinkan pada saat itu, masyarakat belum begitu memperdulikan masalah tanggal dan bulan. ${ }^{26}$ Kemudian, pada tahun 1914 peristiwa Geger Samin terjadi. Yakni, Belanda mengadakan pembersihan komunitas Samin. Mereka menyerang, dan membakar desa-desa pusat pertahanan kaum Samin di Jawa Tengah, dan di Jawa Timur. Banyak kaum Samin terbunuh, sedangkan yang selamat tercerai berai. Ki Samin Surosentiko pun diasingkan ke Sawahlunto hingga akhir hayatnya. ${ }^{27}$

Sementara itu, dikatakan sebagai Wong Sikep, karena sikap diam mereka yang disertai dengan tindakan mengucilkan diri dari komunitas masyarakat

\footnotetext{
${ }^{24}$ Badan Statistik Kabupaten Blora, Statistik Padi dan Palawija Kabupaten Blora 2015 (Blora: Badan Statistik Kabupaten Blora, 2016), h. 7.

${ }^{25}$ Mukodi, dan Afid Burhanuddin, "Domestifikasi Perempuan Samin dalam Khasanah Masyarakat Islam Modern", At-Tahrir Jurnal Pemikiran Islam, Vol. 15, No. 2. November 2015, h. 415. h. 14.

26Mukodi dan Afid Burhanuddin, Pendidikan Samin Surosentiko (Yogyakarta: Lingkar Media, 2015),

${ }^{27}$ Retno Hastijanti, "Konsep Sedulur Sebagai Faktor Penghalang Terbentuknya Ruang Eksklusif pada Permukiman Kaum Samin" Jurnal Arsitektur Petra, Vol. 30, No. 2, Desember 2002, h. 133. Poin terpenting harus diperhatikan adalah Kota Sawahlunto adalah salah satu kota di provinsi Sumatera Barat, Indonesia. Kota yang terletak $95 \mathrm{~km}$ sebelah timur laut Kota Padang ini, dikelilingi oleh 3 kabupaten di Sumatera Barat, yaitu Kabupaten Tanah Datar, Kabupaten Solok, dan Kabupaten Sijunjung. Kota Sawahlunto memiliki luas $273,45 \mathrm{~km}^{2}$ yang terdiri dari 4 kecamatan dengan jumlah penduduk lebih dari 54.000 jiwa. Pada masa pemerintah Hindia Belanda, Kota Sawalunto dikenal sebagai kota tambang batu bara. Kota ini sempat mati, setelah penambangan batu bara dihentikan. Saat ini Kota Sawahlunto berkembang menjadi kota wisata tua yang multietnik, sehingga menjadi salah satu kota tua terbaik di Indonesia. Lihat, https://sawahluntokota.go.id.
} 
biasa. Sikep berarti isiné sing diakep (isinya yang diambil), sedangkan dikatakan sebagai Wong Ādam karena komunitas ini mengaku sebagai pengikut Agama $\bar{A} d a m$. Mengenai penyebutan kata 'Agama $\bar{A} d a m^{\prime}$ ' hingga kini masih ditafsirkan berbeda, dan simpang siur antar satu peneliti dengan lainnya. ${ }^{28}$ Di sisi yang sama, Wong Samin, Wong Sikep, atau Wong Ädam juga dikenal sebagai masyarakat Samin. Suku ini dalam perjalanannya pun menjadi bagian yang tak terpisahkan dalam perlawanan melawan penjajah Belanda. ${ }^{29}$

Dalam konteks keberagamaan — keislaman — kaum Samin termasuk dalam kategori penganut Islam Abangan sebagaimana klasifikasi pengategorian Clifford Geertz. Islam Abangan adalah penyebutan untuk golongan penduduk Jawa Muslim yang mempraktikkan Islam dalam versi yang lebih sinkretis apabila dibandingkan dengan golongan santri yang lebih ortodoks. ${ }^{30}$ Secara historis, label Islam Abangan yang disematkan kepada suku Samin tidak dapat terlacak kebenarannya. Hanya saja, label itu menempel begitu saja seiring berkembangnya foklor perjuangan heroik kaum Samin di masyarakat.

Konstruksi labeling Islam Abangan komunitas Samin pada hakikatnya bertumpu pada beragam penanda yang dipraktikkan mereka dalam kehidupan keseharian. Salah satunya adalah praktik perkawinan adat yang berlangsung dalam kaum Samin. Prosesi perkawinan biasanya diawali dengan pengucapan kalimat syahadat ala kaum Samin, "Witjeng nabi jenengé lanang damelé rabi tatatata jeneng wédok pengaran (......) kukuh demen janji buk nikah empun kulo lakoni." Arti bebasnya, "Sejak Nabi Adam pekerjaan saya memang kawin, (kali ini) mengawini seorang perempuan yang bernama (......). Saya berjanji setia padanya. Hidup bersama telah kami jalani berdua". ${ }^{31}$

Selain itu, penanda lainnya adalah tatkala komunitas Samin diminta berjanji, atau sebuah ikatan mereka tidak pernah mengatakan kata kepastian. Namun, mereka mengatakan "ya karuane", atau "ya lane apo" (arti bebasnya: ya tergantung, atau ya siapa tahu), dalam Islam dikenal dengan kalimat ingsa

\footnotetext{
28Ibid, h. 415.

${ }^{29}$ Singgih Tri Sulistiyono, "Saministo Phobia", h. 31.

${ }^{30}$ Clifford Geertz, Abangan, Santri, Priyayi dalam MasyarakatJawa (Jakarta: Pustaka Jaya), h. 6.

${ }^{31}$ Hanya saja, praktik perkawinan semacam ini, belakangan sulit dijumpai. Hal ini disebabkan adanya kebijakan pemerintah yang mewajibkan setiap penduduk,--tak terkecuali penduduk komunitas Samin--harus menikah, dan mendaftarkan pernikahannya secara resmi di KUA disinyalir memiliki alasan. Lihat: Mukodi dan Afid Burhanuddin, Pendidikan Samin..., h. 30.
} 
Allah). ${ }^{32}$ Penanda-penanda tersebut, menjadi bagian dari akar Islam Abangan yang dilekatkan pada komunitas Samin Surosentiko. Walau sesungguhnya Ki Samin Surosentiko sendiri pun tidak pernah mendeklarasikan identitas Islam Abangan sebagai labeling dirinya, atau kelompoknya. Hanya saja, pelbagai aktivitasnya momot (bermuatan) nilai-nilai Islam lokal yang identik dengan Islam Kejawen, atau Islam Abangan.

Titik pangkal pelacakan Islam Abangan yang dilekatkan pada komunitas Samin di Blora masih rapuh, dan sulit dilacak kebenarannya. Hal ini dikarenakan minimnya dokumentasi, dan referensi yang mengaitkan antara Islam, dan komunitas Samin Surosentiko. Poin terpenting yang perlu dipahami adalah aktivitas keseharian yang momot nilai-nilai Islam menjadi salah satu titik pijak akar kesejarahan Islam Abangan pada komunitas Samin Surosentiko di Blora. Jadi, komunitas Samin Surosentiko Blora dapat dikatakan sebagai pemeluk agama Islam Abangan dalam batas-batas tertentu.

\section{Saminisme: Simbol Nasionalisme Lokal Jawa}

Abdul Munir Mulkhan, mengatakan bahwa "nasionalisme adalah sebuah gagasan mengenai kesatuan kebangsaan dalam suatu wilayah politik kenegaraan."33 Objek formal nasionalisme dalam konsepsi Munir Mulkhan tersebut sesungguhnya adalah manusia, sedangkan objek materialnya adalah aktivitas kebudayaan manusia itu sendiri. Objek material nasionalisme ala komunitas Samin Surosentiko diantaranya: 1) adat istiadat lokal setempat; (gotong royong, saling hormat menghormati, tepa selira —saling menghargai- satu sama lain); 2) pelaksanaan spiritualitas keagamaan ala Jawa; 3) dialektika lokal; 4) pandangan hidup; dan 5) arsitektur rumah Jawa. Kebudayaan komunitas Samin Surosentiko pun mengalir begitu saja. Dinamis, adaptif, tetapi berjiwa. Kondisi itu tidak dapat dilepaskan dari kondisi geografis, dan sosio kultural yang meliputi komunitas masyarakat Samin itu sendiri.

Secara geografis, Desa Kelapodhuwur - tempat komunitas Samin berkembang- merupakan kawasan hutan jati, dan tanah yang kering, tandus

\footnotetext{
${ }^{32}$ Hasil wawancara dengan Mbah Warso, salah satu budayawan dan peneliti dari Blora pada tanggal 23 Juni 2015.

${ }^{33}$ Mulkhan, Abdul Munir, Nasionalisme, Refleksi Kritis Kaum Ilmuan (Yogyakarta: Pustaka Pelajar, 1996), h. 14.
} 
serta berkapur, dan sebagian besar komunitas ini bekerja sebagai petani. Ada yang berladang, berkebun, bercocok tanam, dan berternak. Kebanyakan dari mereka bekerja sebagai petani. Orang-orang dewasa (laki-laki-perempuan) diantara mereka bekerja di sawah, menanam padi, palawija, dan berkebun. Sementara itu, anak-anak mereka membantu orang tuanya masing-masing. Ada yang membantu mengembala sapi, kambing, dan angsa, ada juga yang membantu berladang, merumput, dan lain sepadannya. Kehidupan di dalam komunitas Samin pun berjalan sedemikian rupa, laiknya kehidupan masyarakat Blora, dan masyarakat pedesaan Indonesia pada umumnya. Aktivitas di pagi hari para orang tua pergi ke sawah, ke ladang, anak-anak pergi sekolah. Pada siang, atau sore hari mereka kembali ke rumah dan beristirahat.

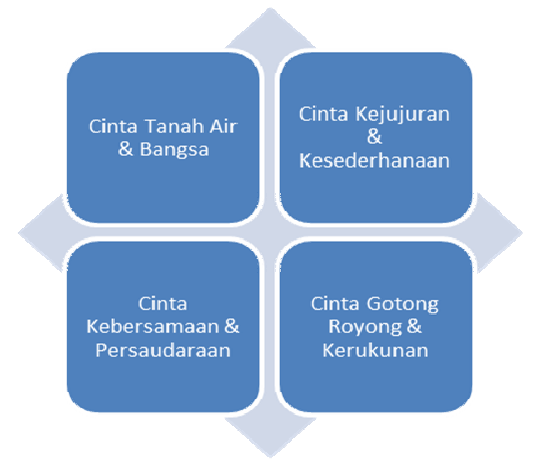

Gambar 3.

Dasar Ajaran Nasionalisme Samin Surosentiko di Blora

Pun demikian adanya dengan nilai-nilai nasionalisme komunitas Samin Surosentiko yang hingga kini masih tetap mengakar dan tumbuh kembang, laiknya kehidupan keseharian masyarakat Samin itu sendiri. Walau siempunya Ki Samin Surosentiko telah lama meninggal, tapi ajaran nilai nasionalisme tetap dipedomani. Setidaknya ada empat dasar ajaran Samin Surosentiko yang terkait dengan nasionalisme yang momot Islam (Jawa) yang hingga kini dipraktikkan. Lihat gambar 3.

Gambar 3 tersebut di atas, merupakan pilar-pilar nasionalisme ala komunitas Samin yang selama ini telah tertanam, dan dipraktikkan dalam kehidupan 
keseharian. Utamanya, diajarkan oleh masing-masing orang tua, dan lingkungan. Adapun penjelasannya lebih lengkap adalah sebagai berikut:

\section{Cinta Tanah Air dan Bangsa}

Secara historis, perjuangan Ki Samin Surosentiko, dan pengikutannya dalam melawan penjajahan tidak terbantahkan lagi. Berikut ini kutipan historis perlawanan heroik kaum Samin dalam melawan Belanda:

"Dhék jaman Londo niku njaluk panjék mboten trimo sak legané nggih mboten diwénéhi, bébas mboten seneng. Ndandhani ratan nggih bebas, nék gelem wis dibébaské. Kéné jaga ya ora, nyang njaga omahé dhéwé. Nyengkah ing negara telun tahun dikenék kerja paksa." (Pada zaman penjajahan Belanda, kalau dipungut pajak akan diberi seikhlasnya, kalau tidak mau malah tidak akan dibayar, terserah kalau Belanda tidak suka. Memperbaiki jalan juga tidak usah [suka-suka]. Tidak perlu jaga malam, lebih baik menjaga rumahnya sendiri. Menolak kerja paksa selama tiga tahun.) ${ }^{34 "}$

Dewasa ini, praktik-praktik cinta tanah, dan kebangsaan dalam wujud yang berbeda tetap saja dilakukan komunitas Samin di Desa Klopo Dhuwur Blora Jawa Tengah. Diantaranya, melalui rasa tanggung jawab. Rasa tanggung jawab dibangun melalui beberapa nilai, diantaranya: ojo nglarani yen ora pingin dilarani (jangan menyakiti jika tidak ingin disakiti); wong nandur bakal panen (siapa yang menanam bakal memetik hasilnya); wong nyilih kudu mbalekno (orang pinjam wajib mengembalikan); wong kang utang kudhu nyaur (orang yang berhutang harus membayar); yen dijiwit loro, ya aja jiwit wong, ojo mbedano marang sepada (jika dicubit sakit, ya jangan cubit orang, jangan membedakan antar sesama). Nilai-nilai tersebut, dijadikan sebagai peredam perilaku masyarakat untuk tidak berlaku secara semena-mena. ${ }^{35}$

\section{Cinta Kejujuran dan Kesederhanaan}

Kejujuran merupakan salah satu sifat yang dijaga, dan diajarkan oleh komunitas Samin Blora hingga kini. Praktik prilaku kejujuran yang dilakukan oleh komunitas Samin sangat sederhana. Misalnya, jika ada seseorang bertamu, dan si tuan rumah (komunitas Samin) ingin menjamunya, maka si empunya rumah

${ }^{34}$ Mukodi dan Afid Burhanuddin. Pendidikan Samin...h. 46.

35Ibid., h. 84. 
menunjukkan kepada si tamu bahwa hidangannya itu miliknya sendiri, bukan curian. Sebut saja, jika si Samin memasak ayam, maka ayam tersebut dipotong di samping, atau dekat pintu. Tujuannya, agar si tamu dapat menyaksikan kebenaran ayam yang disembelih tersebut.

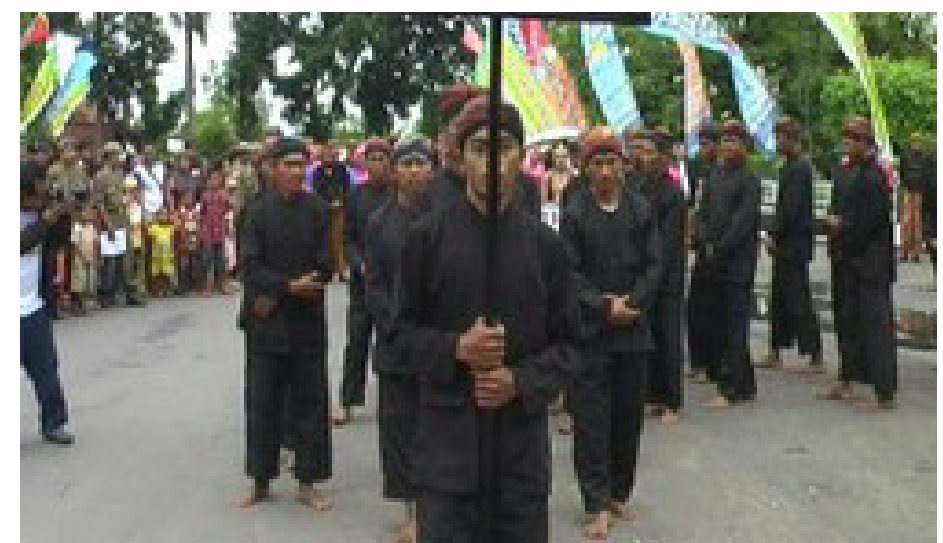

Gambar 4.

Komunitas Samin Kirap Hari Jadi Blora ke-261

Di sisi yang sama, kesederhanaan ditampilkan komunitas Samin dalam hidup keseharian. Misalnya, dalam memenuhi kebutuhan hidup, papan, sandang, dan pangan dilakukan secara sederhana. Pemenuhan papan (rumah) di komunitas Samin dibuat dengan sederhana. Pada suatu saat, tepatnya tanggal 23 September 2015 peneliti pernah bersilaturrahmi ke rumah tokoh komunitas Samin Surosentiko. Ia, merupakan tokoh yang dituakan, dan termasuk keturunan dari muridnya Samin, tetapi rumah cukup sederhana. Rumah tersebut, tidak besar. Ukurannya, kira-kira $7 \times 5 \mathrm{~m}^{2}$ dan berlantai tanah. Dindingnya terbuat dari kayu, dan beratapkan genteng ala kadarnya. Padahal, jumlah ternaknya cukup banyak. Waktu itu, ia memiliki empat ekor sapi, dan delapan kambing. Artinya, jika yang bersangkutan berkeinginan membuat rumah yang representatif cukup untuk modal. Akan tetapi, ia memilih membuat rumah yang sederhana sesuai dengan adat istiadat komunitas Samin.

Demikian pula, model berpakaian komunitas Samin menggunakan prinsip sederhana. Pada umumnya, orang Samin lebih seringkali memakai baju ber- 
warna hitam, dan jelana komprang hitam. Sebab, pakaian serba hitam adalah ciri khas yang merupakan pakaian kebesaran Samin. Hanya saja, sekarang ini pemakaian pakaian kebesaran ini digunakan pada acara-acara tertentu. Dalam keseharian mereka memakai pakaian kebanyakan orang, namun tetap sederhana. Menu makanan yang dimakan mereka pun sederhana. Tidak berlebihan, dan disesuaikan dengan tingkat penghasilan mereka sebagai petani.

Dengan demikian, kejujuran, dan kesederhana tetap saja dipraktikkan oleh komunitas Samin walau si empunyai sudah lama meninggal. Akan tetapi, laku kejujuran, dan sederhana tetap dipraktikkan oleh pengikutnya di Kelopodhuwur Blora.

\section{Cinta Kebersamaan dan Persaudaraan}

Cinta kebersamaan, dan persaudaraan pada hakikatnya termanifestasikan pada sosok Ki Samin Surosentiko. Ki Samin selalu berpegang pada prinsip sinten mawon kulo aku sedulur. ${ }^{36}$ Bahkan, masyarakat Samin mempunyai falsafah bejok reyot iku dulure, waton menungso tur gelem didaku sedulur. ${ }^{37}$ Arti bebasnya "kaki yang pincang itu saudara, asalkan ia manusia yang mau diakui sebagai saudara". Falsafah inilah yang pada akhirnya melahirkan rasa persaudaraan yang kuat di kalangan pengikutnya. Rasa kebersamaan merupakan ajaran terpokok yang dikembangkan oleh Samin Surosentiko. Kaidah yang digunakan adalah sami-sami yang berarti sebagai sesama manusia harus bertindak "sama-sama", sama-sama bertindak jujur, sama-sama adil, sama-sama saling menolong, demi terciptanya masyarakat yang homogen dan guyub.

Lebih dari itu, ia menggunakan istilah sedulur (saudara) untuk membahasakan diri sendiri kepada orang lain. Siapapun dan dalam kondisi yang bagaimanapun ketika sudah menjadi bagian dalam komunitas Samin dan benar-benar mau bersunguh-sungguh mengamalkan ajaran Samin Surosentiko, maka ia dianggap sebagai saudara Ajaran tersebut tercermin dalam prinsip sinten mawon kulo aku sedulur (siapa saja saya anggap sebagai sau-

\footnotetext{
36Ibid., h. 73.

${ }^{37}$ Subarkah, dan Anggit Wicaksono, "Perlawanan Masyarakat Samin Sedulur Sikep Atas Kebijakan Pembangunan Semen Gresik di Sukolilo Pati: Studi Kebijakan Berbasis Lingkungan dan Kearifan Lokal”, Jurnal Pena:Jurnal Ilmu Pengetahuan dan Teknologi, Vol 26, No 2 Maret 2014, h. 178.
} 
dara). ${ }^{38}$ Dengan demikian, jiwa persaudaraan menjadi bagian yang tak terpisahkan dari kehidupan masyarakat Samin di Blora.

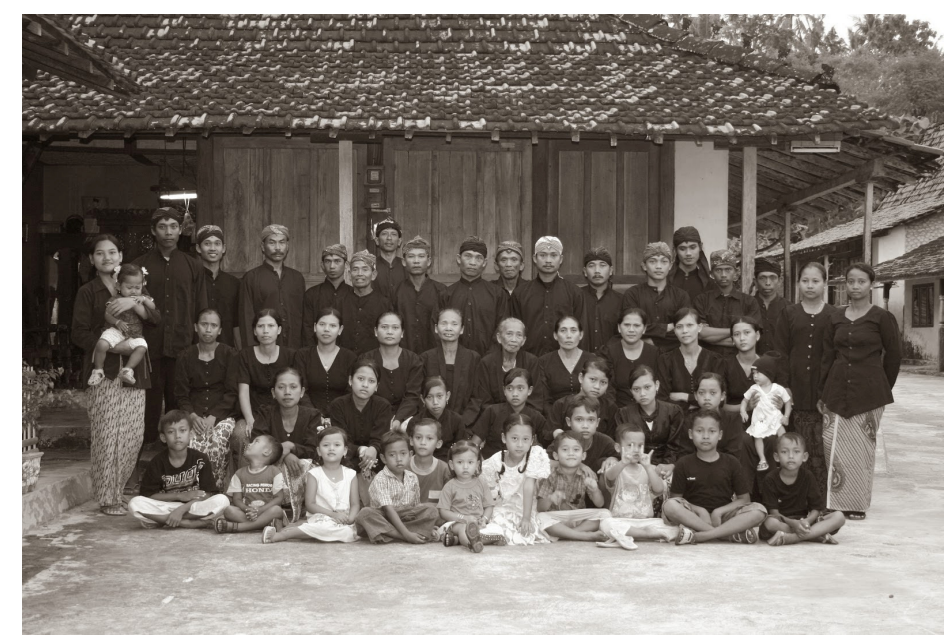

\section{Gambar 5.}

Komunitas Samin Sedang Berfoto di Depan Rumah

\section{Cinta Gotong Royong dan Kerukunan}

Seperti masyarakat Indonesia pada umumnya, komunitas Samin Surosentiko juga cinta gotong royong, dan kerukunan. Gotong-royong mengungkapkan kehendak baik yang harmonis, kesadaran bermasyarakat dan kesediaan untuk saling memperingankan beban. Apabila diantara orang Samin ada yang mempunyai gawé (hajat), yang menurut istilah mereka disebut adang akéh, semua kerabatnya datang dari segala pelosok dengan membawa bahan-bahan mentah yang akan dimasak dan dimakan bersama. Seperti yang diajarkan oleh Samin Surosentiko, bahwa dalam hidup di masyarakat harus tertanam rasa gilir-gumanti. 39

Sementara itu, kerukunan komunitas Samin ditunjukkan melalui kehidupan mereka yang saling asah, asih, dan asuh antar sesama. Wahana untuk me-

38Mukodi dan Afid Burhanuddin, Pendidikan Samin..., h. 73.

${ }^{39}$ Ibid., h. 33. 
lakukannya salah satunya melalui kegiatan adang akeh. Acara ini dilakukan hanya jika ada hajatan, atau kepentingan yang melibatkan tetangga, dan orang banyak. Lihat kutipan berikut:

“... menawi kepengin motong ayam kedah wonten syarate (kalau ingin memakan daging ayam ada syaratnya), nggih niku mbukak gedek (membuka dinding kayu), artinya mempunyai hajat..."

Kutipan tersebut, secara eksplisit menggambarkan bagaimana komunitas Samin Surosentiko senantiasa membudayakan gotong royong, dan kerukunan bertetangga dalam keseharian. Adanya kegiatan rewang (membantu masak) pada saat hajatan, atau kenduri di rumah si empunya komunitas Samin Brola terbukti meningkatkan kerukunan, dan semangat gotong royong. Kondisi ini terlihat dari banyaknya tetangga, dan handai taulan yang datang dan membantu. Padahal, si empunyai rumah tidak meminta bantuan kepada mereka. Nyatanya, mereka tetap berdatangan tatkala mendengar ada tetangga mereka yang punya hajat. Biasanya kaum perempuan datang sambil membawa bahan pokok ala kadarnya, dan alat masak, sedangkan para laki-laki membawa cangkul, sabit, atau pisau untuk membantu keperluan dapur.

Dalam konteks itu, empat dasar ajaran Samin Surosentiko tersebut di atas, menunjukkan bahwa kebudayaan Saminisme Blora tidak hanya menjadi simbol nasionalisme ala Jawa, melainkan juga sebagai wujudnya komunitas Samin dalam mempertahankan NKRI, dan melaksanakan ajaran agama (Islam) Jawa. Dengan demikian, antara agama (Islam) Jawa, dan kebudayaan lokal menjadi satu kesatuan yang tidak dapat dipisahkan dalam lanskap-lanskap kehidupan nyata keseharian.

\section{E. Kesimpulan}

Islam (Jawa) abangan, dan nasionalisme di komunitas Samin Surosentiko Blora menjadi satu kesatuan yang tak terpisahkan. Islam (Jawa) abangan di satu pihak, dipeluk, dan dipedomani sebagai agama formal. Nasionalisme dipihak lainnya, menjadi bagian dari spirit perjuangan anti penindasan yang hingga kini dijaga, dan ditumbuhkembangkan. Titik tolak Islam Abangan dan nasionalisme di kalangan komunitas Samin untuk sementara diasumsikan berasal nilai Islam dan ajaran Samin yang berakomodasi dalam proses budaya yang spesifik bagi komunitas Samin. 
Konsistensi pengamalan ajaran Ki Samin Surosentiko yang dilakukan oleh komunitas Samin pada hakikatnya merupakan perekat antara Islam Abangan, dan nasionalisme. Titik temu Islam Abangan, dan nasionalisme adalah praktik keseharian komunitas Samin yang bertumpu pada ajaran Ki Samin Surosentiko, dan reproduksi nilai-nilai budaya lokal yang dibuat mereka berbasis pada si empunya ajaran.Pola reproduksi nilai-nilai budaya lokal yang berbasis pada nilai ajaran Ki Samin Surosentiko tersebut telah memunculkan kekuatan untuk bertahan di antara perubahan sosial yang terjadi di sekitarnya[w] 


\section{BIBLIOGRAFI}

Aziz, Munawir, "Identitas Kaum Samin Pasca Kolonia Pergulatan Negara, Agama, dan Adat dalam Pro-Kontra Pembangunan Pabrik Semen di Sukolilo, Pati, Jawa Tengah" Jurnal Kawistara, Vol. 2, No. 3, Desember 2012.

Badan Statistik Kabupaten Blora, Blora dalam Angka: Blora in Figures 2016, Blora: Badan Pusat Statistik Kabupaten Blora, 2016.

Badan Statistik Kabupaten Blora, Statistik Padi dan Palawija Kabupaten Blora 2015, Blora: Badan Statistik Kabupaten Blora, 2016.

Choliq Murod, Abdul, "Nasionalisme dalam Pespektif Islam” Jurnal Sejarah Citra Lekha, Vol. XV, No. 2, Agustus 2011.

Fitria, Vita, "Interpretasi Budaya Clifford Geertz: Agama sebagai Sistem Budaya”, Jurnal Sosiologi Reflektif, Vol. 7. No. 1, Oktober, 2012.

Geertz, Clifford, Abangan, Santri, Priyayi dalam Masyarakat Jawa, Jakarta: Pustaka Jaya, 1956.

al-Haythami, al-Ḥafiz, Musnad al-Ḥārith .

Hastijanti, Retno, "Konsep Sedulur Sebagai Faktor Penghalang Terbentuknya Ruang Eksklusif pada Permukiman Kaum Samin”, Jurnal Arsitektur Petra. Vol. 30, No. 2, Desember 2002.

https://id.wikipedia.org/wiki/Kota_Sawahlunto.

https://m.tempo.co/read/news/2016/01/27/063739957/ini-daftarperingkat-korupsi-dunia-indonesia-urutan-berapa.

http://www.antaranews.com/berita/474528/bnn-transaksi-narkobaindonesia-tertinggi-se-asean.

http://www.awas-aja.com/2016/02/7-kasus-terorisme-heboh-terbesarindonesia.html

http://www.bbc.com/indonesia/berita_indonesia/2016/02/160218_indonesi a_radikalisme_anak_muda.

http://www.cnnindonesia.com/nasional/20160318100313-12-

118220/diduga-menghina-lambang-negara-dahsyat-terancamdihentikan/ 
Lestari, Puji, "Analisis Perubahan Sosial pada Masyarakat Samin: Studi Kasus di Desa Mendenrejo, Kecamatan Kradenan, Blora" Jurnal Dimensia, Vol. 2, No. 2, September 2008.

Mukodi, \& Burhanuddin, Afid, "Domestifikasi Perempuan Samin dalam Khasanah Masyarakat Islam Modern", At-Tahrir Jurnal Pemikiran Islam, Vol. 15, No.2. November 2015.

Pendidikan Samin Surosentiko, Yogyakarta: Lingkar Media, 2015.

Mulkhan, Abdul Munir, Nasionalisme, Refleksi Kritis Kaum Ilmuan, Yogyakarta: Pustaka Pelajar, 1996.

Puji Lestari, Indah, "Interaksi Sosial Komunitas Samin dengan Masyarakat Sekitar", Jurnal Komunitas, Vol. 5, No. 1, Maret, 2013Maret, 2013.

Rohman, Arif, "Rumour and Realities of Marriage Parctices in Contemporary Samin Society, Jurnal Humaniora, Vol. 22, No. 2, Juni, 2010.

Sadiran, "Pendidikan Moral Pada Masyarakat Samin Blora", Jurnal Al-Mabsut, Vol. 6, No. 1, April 2013.

Suastika, I. Nengah, "Nasionalisme dalam Perspektif Postmodernisme, Poststrukturalisme dan Postkolonialisme," Jurnal Media Komunikasi, Fakultas Ilmu Sosial, Universitas Pendidikan Ganesha, Singaraja, Vol. 11 , No 1, April 2012,

Tri Sulistiyono, Singgih, "Saministo Phobia” Jurnal Sejarah Citra Lekha, Vol. XVI, No. 2 Agustus 2011.

Vinna Octaviani, Emillia, "Pola Komunikasi Suku Samin di Kabupaten Blora Terkait Ajaran yang Dianutnya”, Jurnal The Messenger, Vol. VII, No. 2, Edisi Juli 2015.

Wicaksono, Anggit, dan Subarkah, "Perlawanan Masyarakat Samin Sedulur Sikep Atas Kebijakan Pembangunan Semen Gresik Di Sukolilo Pati: Studi Kebijakan Berbasis Lingkungan dan Kearifan Lokal", Jurnal Pena Jurnal Ilmu Pengetahuan dan Teknologi, Vol 26, No. 2 Maret 2014.

Zusron Alfaqi, Mifdal, "Memahami Indonesia Melalui Prespektif Nasionalisme, Politik Identitas, Serta Solidaritas", Jurnal Pendidikan Pancasila dan Kewarganegaraan, No. 2 Agustus 2015. 